UDC $612.35: 612.26: 577.23: 57.042: 57.053 .2$

doi: https://doi.org/10.15407/ubj92.04.014

\title{
MPTP OPENING DIFFERENTLY AFFECTS ELECTRON TRANSPORT CHAIN AND OXIDATIVE PHOSPHORYLATION AT SUCCINATE AND NAD-DEPENDENT SUBSTRATES OXIDATION IN PERMEABILIZED RAT HEPATOCYTES
}

\author{
H. M. MAZUR, V. M. MERLAVSKY, B. O. MANKO, V. V. MANKO \\ Ivan Franko National University of Lviv, Ukraine; \\ ৫e-mail: volodymyr.manko@lnu.edu.ua
}

Received: 10 October 2019; Accepted: 15 May 2020

\begin{abstract}
Mitochondrial $\mathrm{Ca}^{2+}$ overload may trigger the opening of mitochondrial permeability transition pore (mPTP) and its prolonged activation leads to cell death. ATP synthase is considered as a possible molecular component of the pore. The aim of this study was to investigate the state of oxidative phosphorylation at $\mathrm{Ca}^{2+}-$ induced activation of MPTP in permeabilized hepatocytes. Hepatocytes were isolated by two-stage Seglen method. Permeabilization was performed using digitonin. Oxygen consumption rate was measured with Clark electrode. Oxidative phosphorylation was determined as the ratio of the ADP-stimulated respiration and substrate-stimulated respiration rates (ADP/S). It was established that increasing of $\mathrm{Ca}^{2+}$ concentration in the medium inhibited oligomycin effects and suppressed ADP-and FCCP-stimulated respiration upon succinate or glutamate, pyruvate and malate mixture oxidation. The $\mathrm{mPTP}$ inhibitor cyclosporin A did not directly affect respiration and oxidative phosphorylation after elevation of $\mathrm{Ca}^{2+}$ concentration and MPTP activation. When cyclosporine A was added before increasing $\mathrm{Ca}^{2+}$ concentration, the electron transport chain function (FCCP-stimulated respiration) was not impaired while the partial disruption of oxidative phosphorylation (ADP-stimulated respiration) was observed only upon succinate oxidation. The results obtained showed that inhibition of oxidative phosphorylation was the primary event in mPTP activation, possibly due to the involvement of ATP synthase in pore opening. In the case of NAD-dependent substrates oxidation that effect was stronger and faster than at succinate oxidation, due to the lower mitochondria energization.
\end{abstract}

Keywords: mitochondrial permeability transition pore, cyclosporin A, oxidative substrates, hepatocytes, FCCP.

$\mathrm{Ca}^{2+}$ plays an important role in regulation of many cellular processes. Moderate elevation of $\mathrm{Ca}^{2+}$ concentration in the mitochondrial matrix increases the activity of pyruvate, isocitrate, $\alpha$-ketoglutarate dehydrogenases and ATP synthesis [1]. Territo [2] concludes that $\mathrm{Ca}^{2+}$ activates $\mathrm{F}_{0} \mathrm{~F}_{1}$-ATP-synthase of heart isolated mitochondria. In mitochondria in situ (permeabilized hepatocytes), the effects of $\mathrm{Ca}^{2+}$ on respiration depend on the oxidative substrate [3].

Abnormally high $\mathrm{Ca}^{2+}$ concentration in the matrix of mitochondria (mitochondrial $\mathrm{Ca}^{2+}$ overload) cause opening of mitochondrial permeability transition pore (mPTP), a nonspecific channel in the inner mitochondrial membrane. While physiological role of transient pore activation is still not clear [4], the prolonged $\mathrm{Ca}^{2+}$-induced $\mathrm{mPTP}$ opening leads to the respiration and oxidative phosphorylation uncoupling, ATP depletion and mitochondrial matrix swelling, cytochrome $c$ release and apoptotic cells death [5-8]. In permeabilized hepatocytes rate of uncoupled respiration decreases following the increase of $\mathrm{Ca}^{2+}$ concentration to 1 and $10 \mu \mathrm{M}$ [3].

Despite numerous studies, the complete molecular composition of mPTP still remains unknown. Recently, Giorgio and co-authors suggested that the $\mathrm{F}_{0} \mathrm{~F}_{1}$ subunits of ATP synthase are involved in the mPTP formation [9]. Interestingly, ATP synthase inhibitor oligomycin (Omy) enhances the pro-

(C) 2020 Mazur H. M. et al. This is an open-access article distributed under the terms of the Creative Commons Attribution License, which permits unrestricted use, distribution, and reproduction in any medium, provided the original author and source are credited. 
tective effect of CsA on the mitochondrial permeability transition in rat kidney mitochondria [10]. It is important to study the interaction of mPTP activation and mitochondrial metabolism on cell models with retention of multiple intracellular processes, as many MPTP properties were discovered on isolated mitochondria, but not in cells [4].

Therefore, the goal of this study was to investigate the state of oxidative phosphorylation at $\mathrm{Ca}^{2+}$ induced mPTP opening in permeabilized hepatocytes.

\section{Materials and Methods}

Reagents were purchased from Sigma-Aldrich (sodium chloride, glucose, N-2hydroxyethylpiperazine-N'-2-ethanesulfonic acid, bovine serum albumin, sodium pyruvate, glutamic acid, malic acid, a-ketoglutaric acid, succinic acid, Ethylene glycol-bis(2-aminoethylether)-N, $\mathrm{N}, \mathrm{N}, \mathrm{N}$-tetraacetic acid, carbonyl cyanide4-(trifluoromethoxy) phenylhydrazone, collagenase type IV, Cyclosporin A) or Merck Chemicals (Calcium chloride dihydrate). All other reagents were of purest available grade.

Experiments were performed on 180-220 g male Wistar rats. The animals were kept under stationary vivarium conditions at a constant temperature and the standard diet. All manipulations with animals were carried out according to the European Convention for the Protection of Vertebrate Animals used for Experimental and other Scientific Purposes, and the Law of Ukraine "On protection of animals from cruelty".

Before the experiment, the animals starved for 18 hours with free access to water. Hepatocytes were isolated by two-stage Seglen method [11]. Animals were anesthetised with diethyl ether and decapitated. Abdominal dissection was made and a liver was extirpated rapidly.

The liver was perfused with calcium-free EGTA-containing extracellular chilled solution to wash out the blood. At the next stage recirculating perfusion of the liver with calcium-containing collagenase solution ( 108 units $/ \mathrm{ml})$ for $10-12 \min \left(37^{\circ} \mathrm{C}\right)$ was performed. After digestion of the collagen matrix, organ was perfused with basic extracellular medium to wash out collagenase. Liver was transferred then into the basic extracellular medium containing, $\mathrm{mM}: \mathrm{NaCl}-140.0, \mathrm{KCl}-4.7, \mathrm{CaCl}_{2}-1.3, \mathrm{MgCl}_{2}-$ 1.0, glucose - 5.0, HEPES - 10.0; $\mathrm{pH} 7.4$.
Isolated hepatocytes were dispersed afterwards by gentle pipetting. Suspension was filtered through the nylon mesh $(0.1 \times 0.1 \mathrm{~mm}(100 \mu \mathrm{m}))$ to exclude clots of the cells. The cells were centrifugated thrice at $50 \mathrm{~g}$ to remove metabolites, residues of extracellular matrix and damaged hepatocytes. Hepatocytes were counted with haemocytometer. The plasma membrane integrity of hepatocytes was evaluated by staining the cells with $0.1 \%$ trypan blue solution. The number of intact cells was $81-85 \%$.

Permeabilization was performed using digitonin $(50 \mathrm{mg} / \mathrm{ml})$ for $10 \mathrm{~min}$ at $37^{\circ} \mathrm{C}$. Oxygen consumption rate was measured with Clark electrode (oxygen monitor YSI 5300) in $1.6 \mathrm{ml}$ thermostatic glass chamber at $37^{\circ} \mathrm{C}$. The ratio of the ADP-stimulated respiration $(\mathrm{ADP} / \mathrm{S})$ or $\mathrm{FCCP}$-stimulated respiration $(\mathrm{FCCP} / \mathrm{S})$ rate to the substrate-stimulated respiration rate were used as respiratory control indices.

Mathematical and statistical analysis of the data was performed using the software package Microsoft Excel. Statistical significance of difference between groups was determined with Student's $t$-test.

\section{Results and Discussion}

Cyclosporin A (CsA) is able to block this pore and prevent the disturbance of mitochondrial functions $[12,10,13]$. Thus we used CsA to test its effects of $\mathrm{Ca}^{2+}$-induced mPTP activation on respiration of digitonin-permeabilized hepatocytes. Hepatocytes were added during the first series of experiments into a polarographic chamber where oxidation substrates - succinate $(5 \mathrm{mM})$ or a mixture of malate, glutamate and pyruvate $(5 \mathrm{mM})$ were present already at different $\mathrm{Ca}^{2+}$ concentrations. The following agents were added into polarographic chamber subsequently in this order: ADP $(750 \mu \mathrm{M})$, olygomycin (Omy, $3 \mu \mathrm{M})$, cyclosporin A $(\mathrm{CsA}, 0.5 \mu \mathrm{M})$ and FCCP (two additions to the final concentration of 0.05 and $0.1 \mu \mathrm{M})$ and the changes in the oxygen consumption were recorded (Fig. 1, $A$ and 2, A).

It was established that respiration rate at succinate oxidation was significantly higher by $\sim 35 \%$ in case of the highest $\mathrm{Ca}^{2+}$ concentration, $10 \mu \mathrm{M}$ $(P=0.02$; Fig. $1, B, D)$. The addition of ADP into the polarographic chamber at succinate oxidation stimulated respiration of permeabilized hepatocytes in the mediums with $0.1 \mu \mathrm{M} \mathrm{Ca}^{2+}(P=0.0000002)$ or $1 \mu \mathrm{M}$ $\mathrm{Ca}^{2+}(P=0.000006)$ two-fold. When $10 \mu \mathrm{M} \mathrm{Ca}^{2+}$ was present, respiration was only slightly stimulated, and was significantly lower comparing to $0.1 \mu \mathrm{M} \mathrm{Ca}^{2+}$ 
$(P=0.01$; Fig. $1, B)$. The addition of Omy into the chamber (at ADP presence) reduced the hepatocytes respiration rate compared to previous respiration state at all $\mathrm{Ca}^{2+}$ concentrations tested, although the Omy effect was significantly less pronounced at the higher $\mathrm{Ca}^{2+}$ concentrations $(1$ and $10 \mu \mathrm{M} ; P=0.005$ and $P=0.04$; Fig. $1, B$ ). CsA caused slight decrease of the respiration rate of hepatocytes compared to Omy-inhibited respiration, yet after CsA action in case of $1 \mu \mathrm{M} \mathrm{Ca}^{2+}(P=0.04)$ or $10 \mu \mathrm{M} \mathrm{Ca}^{2+}(P=0.01)$ respiration rate was still higher than at $0.1 \mu \mathrm{M} \mathrm{Ca}^{2+}$ (Fig. 1, B). Subsequently, FCCP $(0.05 \mu \mathrm{M})$ raised the uncoupled respiration to the ADP-stimulated level both at 0.1 and $1 \mathrm{Ca}^{2+}(P=0.000009$ and $P=0.0004$; Fig. $1, B)$ with no significant effect at $10 \mu \mathrm{M} \mathrm{Ca}^{2+}$. The elevation of FCCP concentration to $0.1 \mu \mathrm{M}$ caused slight decrease of respiration rate at $1 \mu \mathrm{M}$ $(P=0.04)$ or $10 \mu \mathrm{M}(P=0.002) \mathrm{Ca}^{2+}$.

The inhibition of ADP and Omy effects by $10 \mu \mathrm{M} \mathrm{Ca}^{2+}$ is an evidence of oxidative phosphorylation processes suppression. In addition, FCCPuncoupled respiration rate was also substantially redused, suggesting the impairment of electron transport chain function. This is consistent with
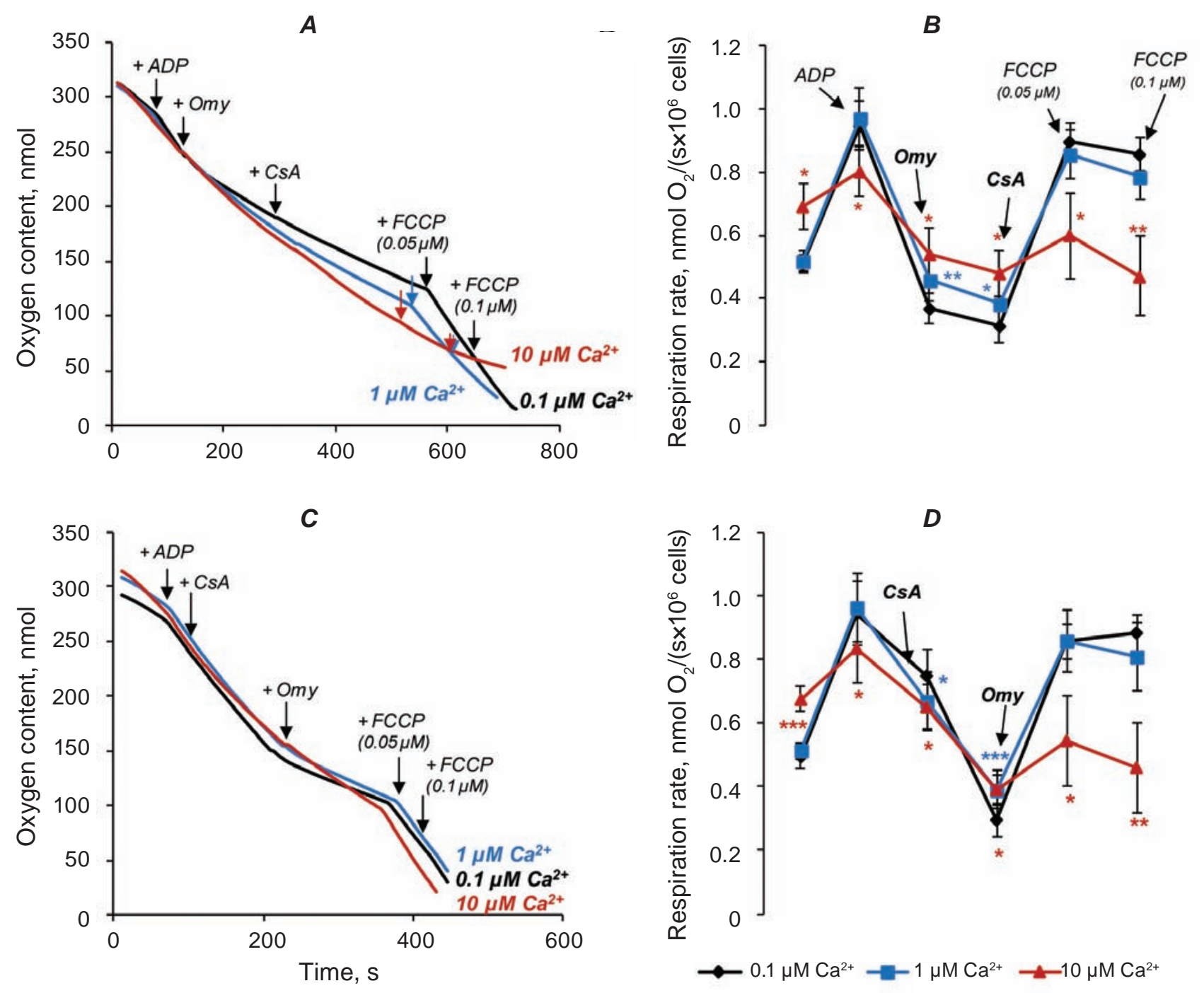

Fig. 1. Effect of CSA on the permeabilized hepatocytes respiration rate at succinate oxidation in media with 0.1, 1 and $10 \mu M \mathrm{Ca}^{2+}$ : original record of oxygen consumption by the hepatocytes suspension at successive addition of Omy - CsA (A) or CsA - Omy (C) into the chamber; hepatocytes respiration rate at successive addition of Omy - CsA (B) or CsA - Omy (D) into the chamber; [succinate] $=5 \mathrm{mM},[A D P]=750 \mu M$, $[C s A]=0.5 \mu \mathrm{M},[\mathrm{Omy}]=3 \mu \mathrm{M},[\mathrm{FCCP}]=0.05$ and $0.1 \mu \mathrm{M}$; via asterisk the statistically significant difference was denoted just compared to $0.1 \mu M \mathrm{Ca}^{2+}$ with ${ }^{*} P<0.05$, ${ }^{* *} P<0.01$ or $* * * P<0.001 ; n=7$ 
known pathological effects of very high $\mathrm{Ca}^{2+}$ concentrations on mitochondria due to strong depolarization of the mitochondrial inner membrane and/or violation of the negative feedback between the mitochondrial membrane potential and respiration [14].

In other series of experiments, we added CsA before Omy to assess its direct effect on oxidative phosporylation. In this case, the respiration after CsA action decreased significantly stronger at 1 or $10 \mu \mathrm{M} \mathrm{Ca}^{2+}$ (both $P=0.04$ ). The effects of Omy and FCCP were similar to the first experimental series (Fig. 1, C, D).
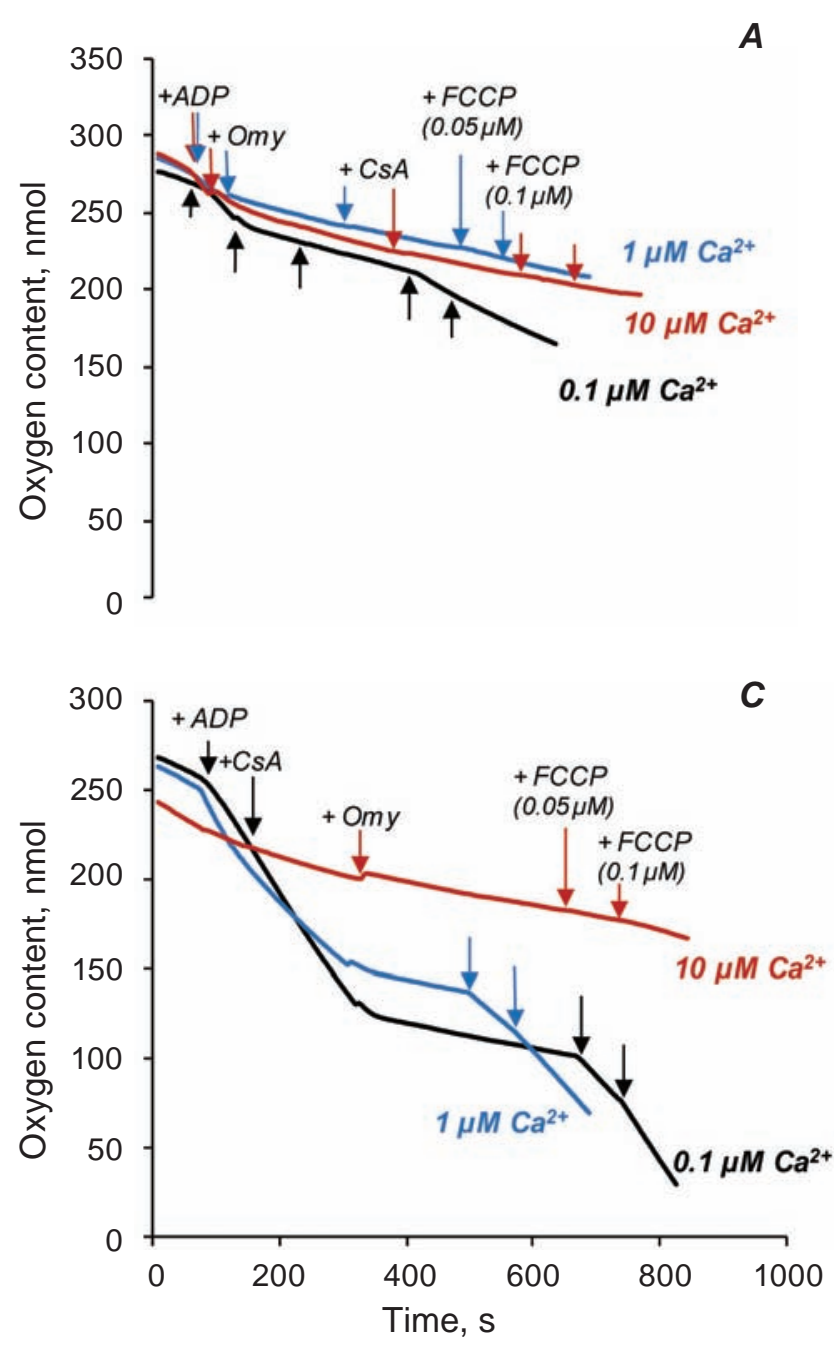

At oxidation of malate, glutamate and pyruvate mixture ADP strongly (2.5-fold) stimulated respiration at $0.1(P=0.00008)$ or $1(P=0.003) \mu \mathrm{M} \mathrm{Ca}^{2+}$, but not at $10 \mu \mathrm{M} \mathrm{Ca}^{2+}$ (Fig. 2, $B$ ). Omy strongly inhibited hepatocyte respiration when $0.1(P=0.0003)$ or $1(P=0.00006) \mu \mathrm{M} \mathrm{Ca}^{2+}$ was present, but almost had no effect with $10 \mu \mathrm{M} \mathrm{Ca}^{2+}(P=0.09)$. The additions of CsA into the chamber (after Omy) slightly inhibited hepatocytes respiration in the media with 1 $(P=0.01)$ or $10(P=0.01) \mu \mathrm{M} \mathrm{Ca}^{2+}$ but not at $0.1 \mu \mathrm{M}$ $\mathrm{Ca}^{2+}$. FCCP in low concentration $(0.05 \mu \mathrm{M})$ stimulated respiration only at $0.1 \mu \mathrm{M} \mathrm{Ca}^{2+}(P=0.01)$, in
$A$
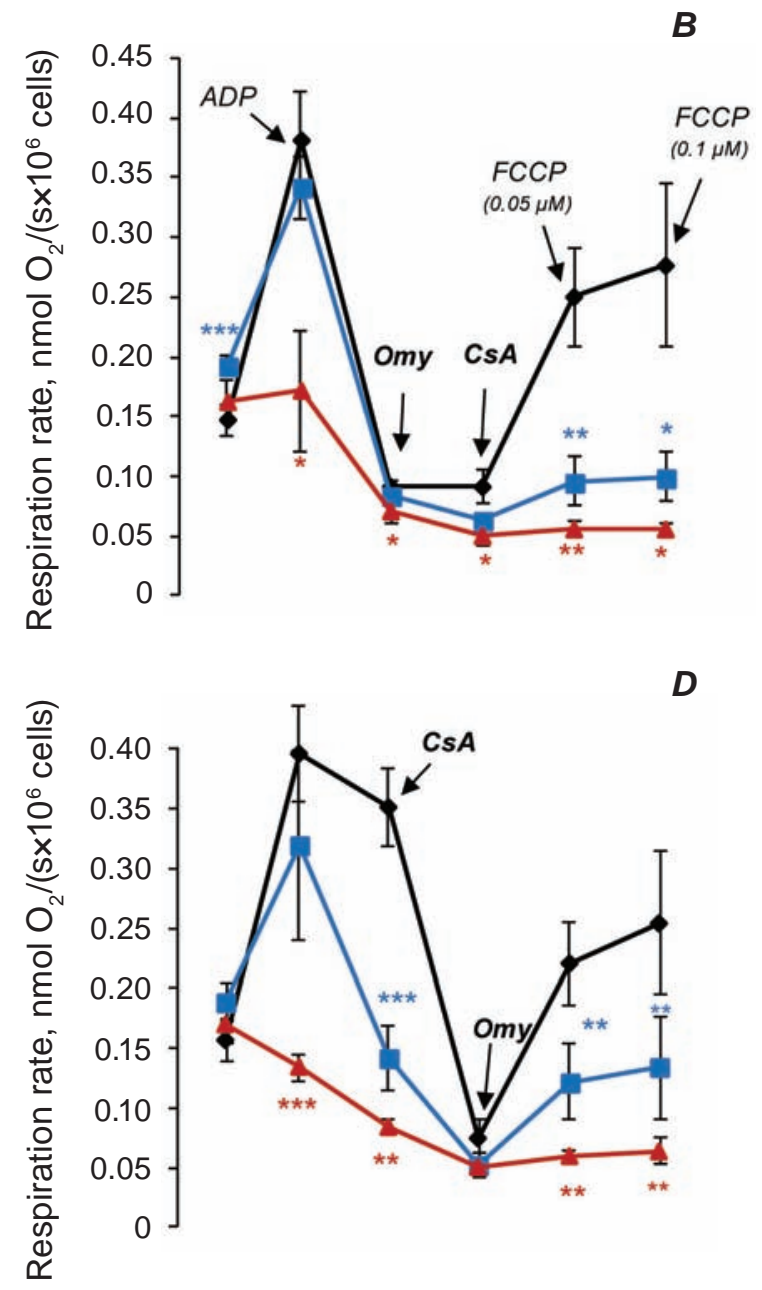

Fig. 2. Effect of CsA on the permeabilized hepatocytes respiration rate at oxidation of malate, glutamate and pyruvate mixture in media with $0.1,1$ and $10 \mu \mathrm{MCa}^{2+}$ : original record of oxygen consumption by the hepatocytes suspension at successive addition of Omy-CsA (A) or CsA-Omy (C) into the chamber; hepatocytes respiration rate at successive addition of Omy - CsA (B) or CsA-Omy (D) into the chamber; [malate] $=5 \mathrm{mM}$, [glutamate] $=5 \mathrm{mM}$, [pyruvate] $=5 \mathrm{mM},[\mathrm{ADP}]=750 \mu \mathrm{M},[\mathrm{Cs} A]=0.5 \mu \mathrm{M},[\mathrm{Omy}]=3 \mu \mathrm{M},[\mathrm{FCCP}]=0.05$

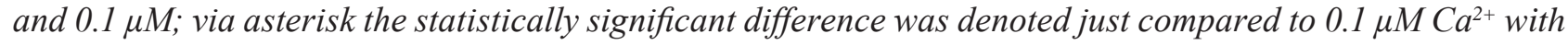
${ }^{*} P<0.05,{ }^{* *} P<0.01$ or ${ }^{* * *} P<0.001 ; n=7$ 
contrast to succinate oxidation. An increase of FCCP concentration to $0.1 \mu \mathrm{M}$ did not further change the respiration rate. When CsA was added prior to Omy, it caused wery strong and significant respiration decrease at $1 \mu \mathrm{M} \mathrm{Ca}^{2+}(P=0.01$; Fig. $2, B)$. The change of CsA addition time in general did not modify the Omy or FCCP action.

Importantly, in all experiments we have observed that level of Omy-inhibited respiration was significantly lower than initial respiration rate. This, in addition to apparent inhibitory CsA effects, which depended on $\mathrm{Ca}^{2+}$ concentration, suggested that accumulation of $\mathrm{Ca}^{2+}$ in minochondria over time might be inhibited the respiration per se. To test this assumption, we studied the time dependence of ADPstimulated hepatocytes respiration rate in media with various $\mathrm{Ca}^{2+}$ concentrations. ADP was added $120 \mathrm{~s}$ after the experiment initiation, and then the respiration rate was recorded for four time intervals - 140$160,325-355,455-485$, and 500-540 s. In alternative experiment, ADP, CsA, Omy and FCCP $(0.05 \mu \mathrm{M})$ were added during the same time periods (Fig. 3, B).
It was established that ADP-stimulated respiration rate decreased with time at all $\mathrm{Ca}^{2+}$ concentrations in control, and these changes were especially strong at $10 \mu \mathrm{M} \mathrm{Ca}^{2+}$ in the medium. In addition, these experiments confirmed no CsA effects on respiration, in contrast to Omy and FCCP (Fig. 3, A). Therefore, the time before CsA addition was sufficient for accumulation of enough $\mathrm{Ca}^{2+}$ in the mitochondria to activate $\mathrm{MPTP}$ and cause irreversible disruption of mitochondrial respiration and oxidative phosphorylation.

At the next stage, we added CsA into the respiratory chamber before elevation of $\mathrm{Ca}^{2+}$ concentration. Increasing $\mathrm{Ca}^{2+}$ concentration in the medium to 1 and $10 \mu \mathrm{M}$ suppressed ADP- and FCCP-stimulated respiration, like in the previous series of experiments. Moreover, that effect did not depend on the oxidative substrate type (Fig. 4, $B$ and 5, B). CsA addition into the chamber before $\mathrm{Ca}^{2+}$ prevented some negative effect of these ions in high concentrations, both at succinate alone (Fig. $4, D$ ) or mixture of substrates oxidation (Fig. $5, D$ ). At succinate oxidation

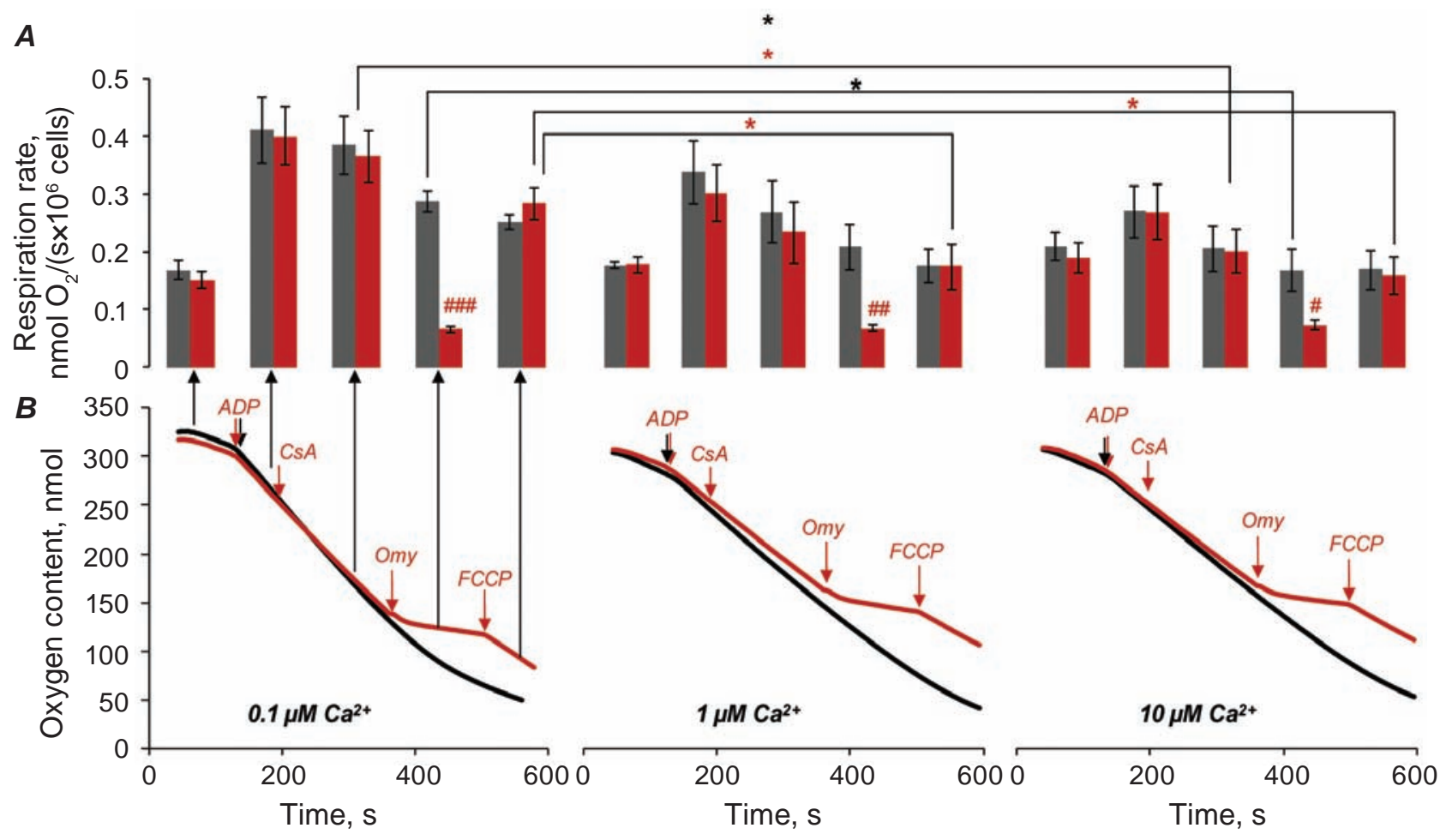

Fig. 3. Hepatocytes respiration is reduced not due to CsA influence: permeabilized hepatocytes respiration rate (A) and original record of oxygen consumption (B) at oxidation of malate, glutamate and pyruvate mixture; [malate] $=5 \mathrm{mM}$, [glutamate] $=5 \mathrm{mM}$, [pyruvate] $=5 \mathrm{mM},[\mathrm{ADP}]=750 \mu \mathrm{M},[\mathrm{Cs} A]=0.5 \mu \mathrm{M}$,

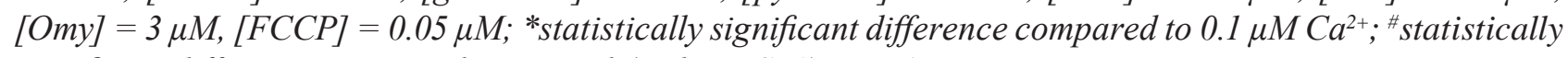
significant difference compared to control (without CSA); $n=6$ 

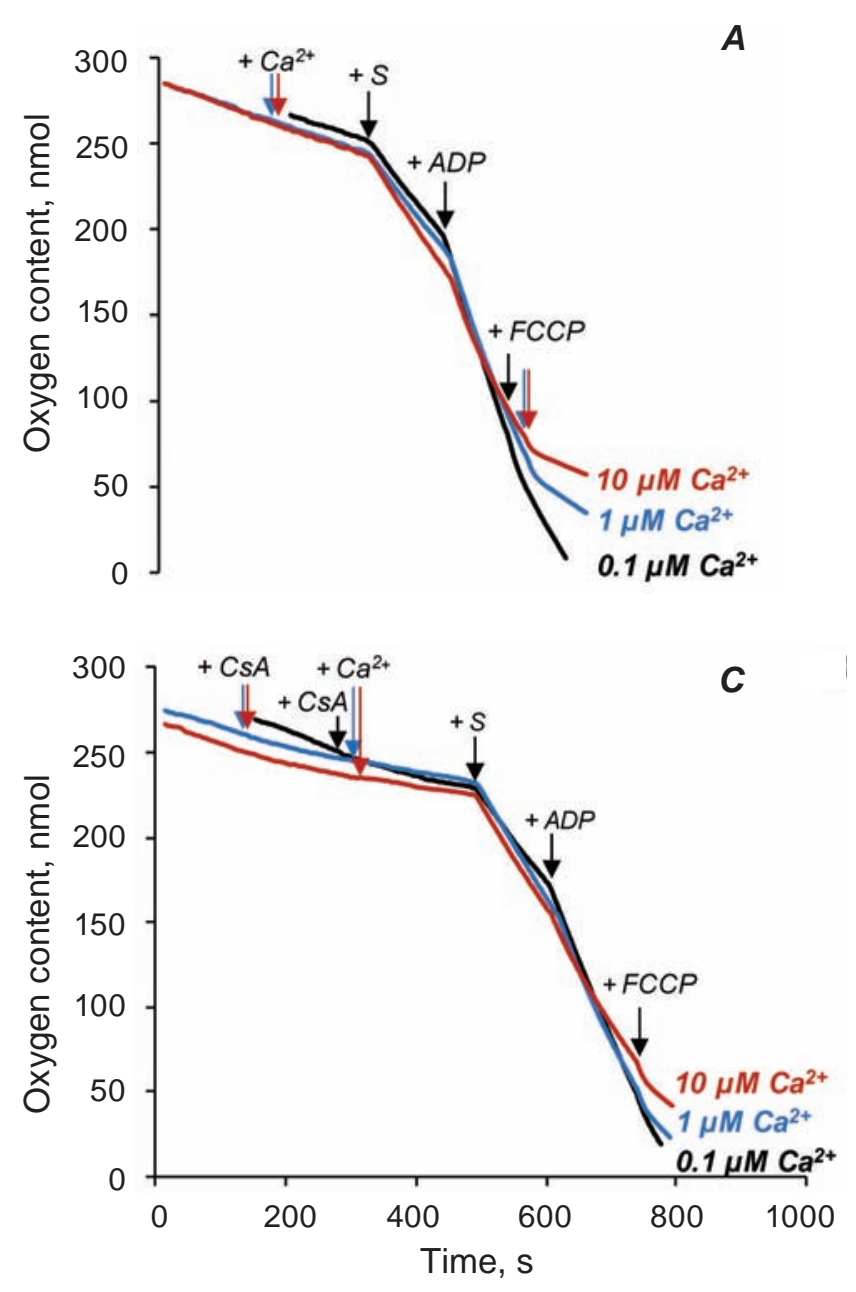

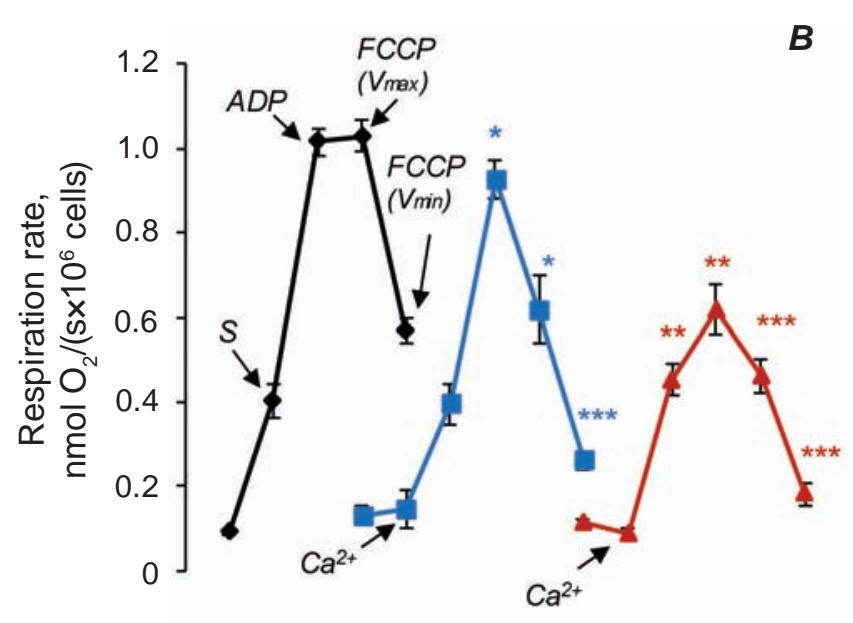

D

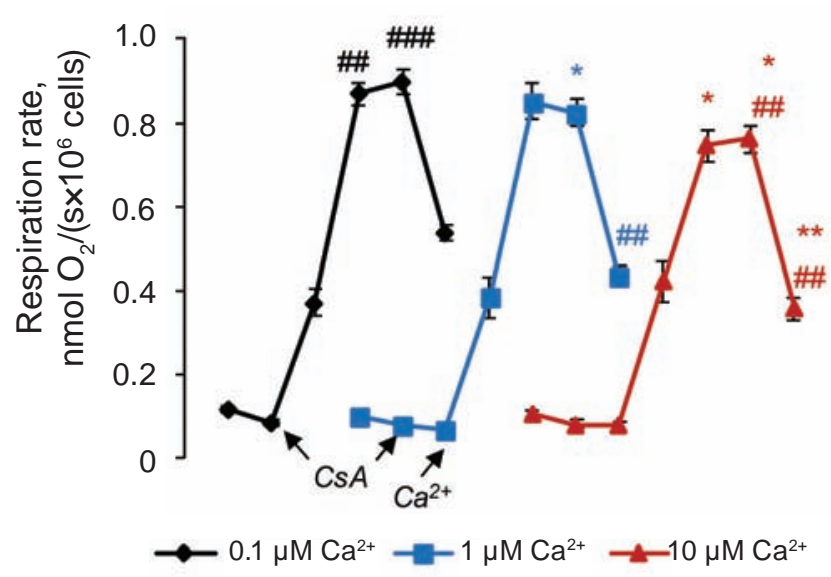

Fig. 4. Effect of CSA on oxygen consumption rate by permeabilized hepatocytes at the succinate oxidation in the mediums with 0.1, 1 and $10 \mu \mathrm{MCa}^{2+}$ : original record of oxygen consumption by the hepatocytes suspension at CsA absence (A) and CsA presence $(C)$ within the medium; hepatocytes respiration at CsA absence (B) and CsA presence (D) within the medium; [succinate] $=5 \mathrm{mM},[C s A]=0.5 \mu M,[A D P]=750 \mu M$, $[F C C P]=0.25 \mu \mathrm{M}$; *statistically significant difference compared to $0.1 \mu \mathrm{M} \mathrm{Ca}^{2+}$; ${ }^{*}$ statistically significant difference compared to control (without CsA); $n=6$

CsA addition prevented the $\mathrm{Ca}^{2+}$-induced decrease of ADP-stimulated and FCCP-stimulated respiration. CsA eliminated the negative effect of $\mathrm{Ca}^{2+}$ in high concentrations on the FCCP-stimulated respiration if mixture of malate, glutamate and pyruvate was present in the medium. However, CsA did not affect the negative effect of $\mathrm{Ca}^{2+}$ in high concentrations on the ADP-stimulated respiration under these conditions.

The conclusion about CsA effect on the ADPstimulated and FCCP-stimulated respiration rate was confirmed by the calculated respiratory controls at succinate or mixture of substrates oxidation. As respiratory control we used the ratio of the ADPstimulated respiration (ADP/S) or FCCP-stimu- lated respiration $(\mathrm{FCCP} / \mathrm{S})$ rate to the respiration rate, registered after oxidative substrate addition. Respiratory control was dependent on the activity of ATP synthase and the oxidative phosphorylation processes in the first case and on the functioning of the mitochondrial respiratory chain only - in the second.

It was found that respiratory controls were significantly reduced as a result of $\mathrm{Ca}^{2+}$ concentration elevation in the medium. That decrease was observed at presence of both succinate or mixture of malate, glutamate and pyruvate. ADP/S and FCCP/S reduction at high $\mathrm{Ca}^{2+}$ concentrations was prevented by CsA at succinate oxidation (Fig. 6, $A$ ). In case 

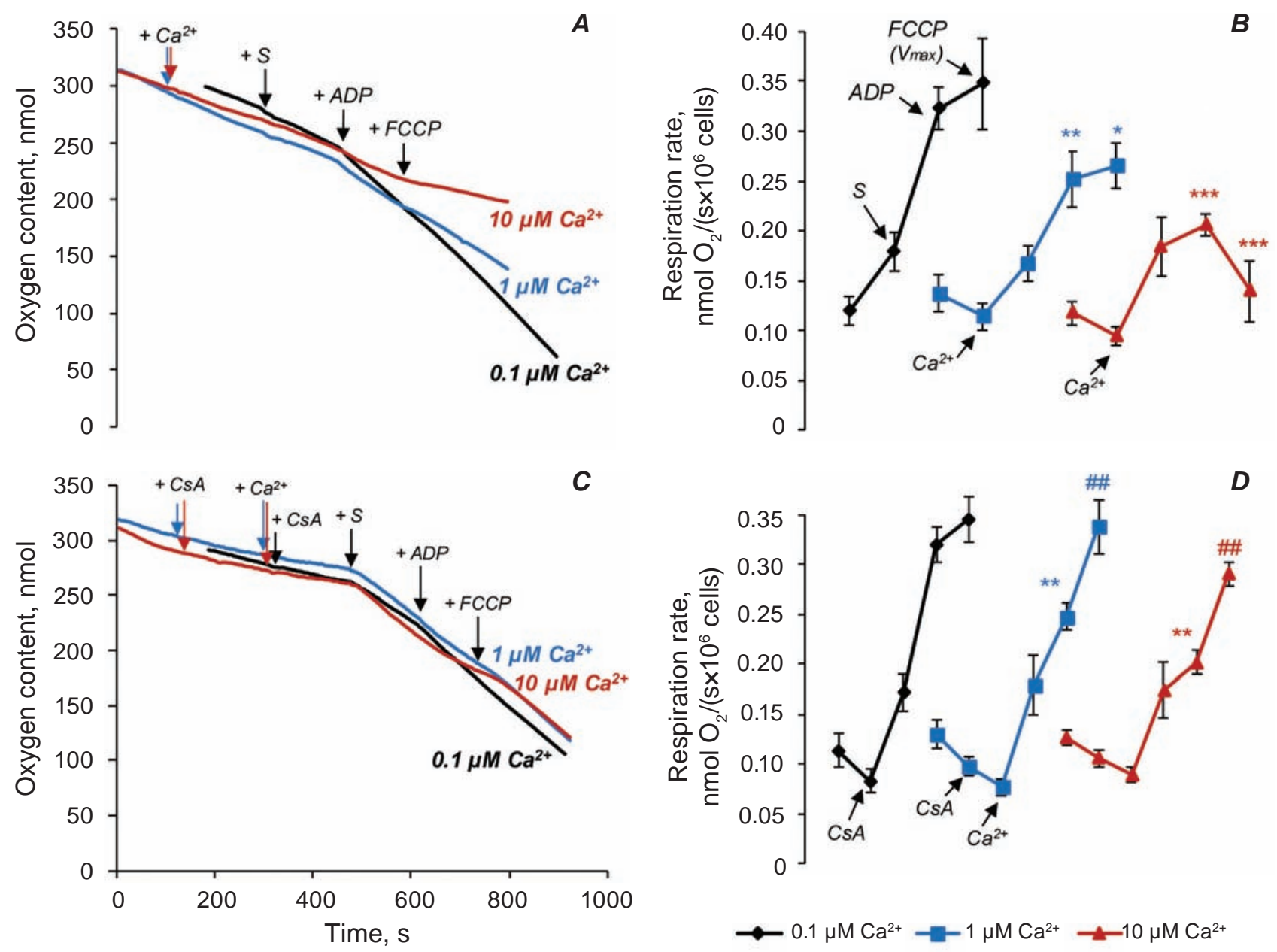

Fig. 5. Effect of CsA on oxygen consumption rate by permeabilized hepatocytes at mixture of malate, glutamate

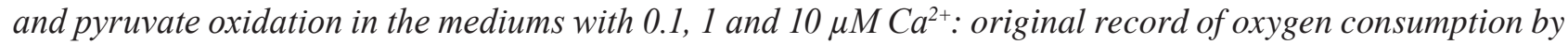
the hepatocytes suspension at CsA absence (A) and CsA presence (C) within the medium; hepatocytes respiration at CsA absence $(\boldsymbol{B})$ and $C s A$ presence $(\boldsymbol{D})$ within the medium; [malate] $=5 \mathrm{mM}$, [glutamate] $=5 \mathrm{mM}$, $[$ pyruvate $]=5 \mathrm{mM},[C s A]=0.5 \mu \mathrm{M},[\mathrm{ADP}]=750 \mu \mathrm{M},[\mathrm{FCCP}]=0.25 \mu \mathrm{M}$; * statistically significant difference compared to $0.1 \mu \mathrm{MCa}^{2+}$; ${ }^{\#}$ statistically significant difference compared to control (without CsA); $n=7$

of malate, glutamate and pyruvate mixture oxidation CsA prevented only FCCP/S decrease, but not ADP/S decrease.

It is known that $\mathrm{Ca}^{2+}$ concentration elevation in the hepatocytes cytoplasm is accompanied by the rapid transport of these cations into the mitochondrial matrix [15]. This translocation is provided by the presence of such systems as "rapid mode" [15], mitochondrial calcium uniporter [16] and mitochondrial ryanodine receptors [17] in the inner mitochondrial membrane.

The $\mathrm{Ca}^{2+}$ flow into mitochondria has an important physiological significance, since it activates three enzymes of the citric acid cycle (pyruvate dehydrogenase, $\alpha$-ketoglutarate dehydrogenase and isocitrate dehydrogenase) [18] and thus regulates respiration and oxidative phosphorylation [19]. Since $\mathrm{Ca}^{2+}$ transport is carried out due to the inner mitochondrial membrane energy, it can stimulate the oxidative phosphorylation just at micromolar concentrations (0.1-0.8 $\mu \mathrm{M})$ in the extramitochondrial medium, when this transport does not significantly reduce the mitochondrial membrane potential [20]. Abnormally high $\mathrm{Ca}^{2+}$ concentrations (as a result of multiple additions to reach final concentration of 10$20 \mu \mathrm{M}$ ) inhibit mitochondrial respiration after initial intensification and reduce mitochondrial membrane potential at oxidation of either succinate or mixture of malate and glutamate [21]. Such changes in mitochondrial respiration and mitochondrial membrane 
$A$
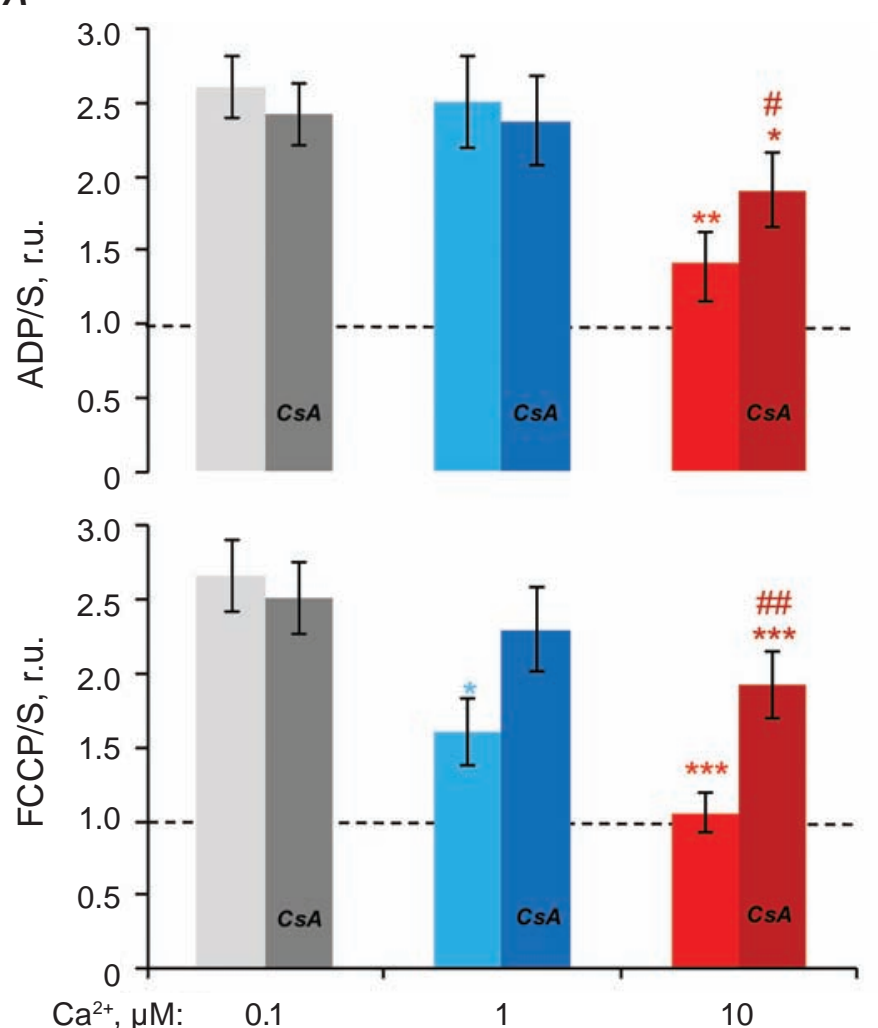

B
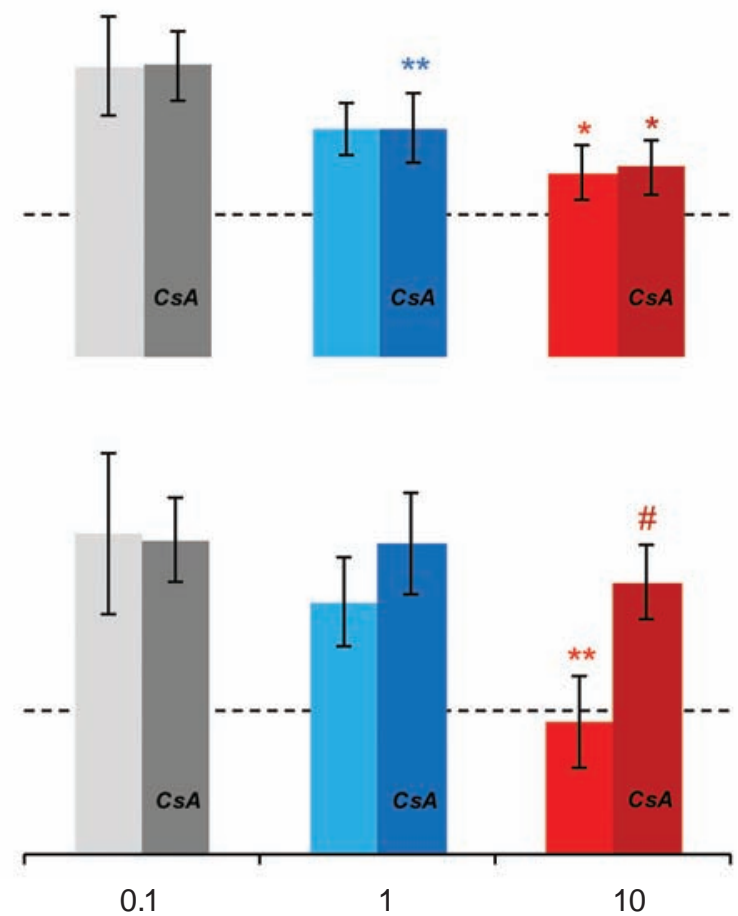

Fig. 6. Respiratory control of permeabilized hepatocytes in the medium containing $0.1,1$ and $10 \mu \mathrm{MCa}{ }^{2+}$ in the absence or presence of CsA: $\boldsymbol{A}$ - at succinate oxidation; $\boldsymbol{B}$ - at mixture of malate, glutamate and pyruvate oxidation; [succinate] $=5 \mathrm{mM}$, [malate] $=5 \mathrm{mM}$, [glutamate] $=5 \mathrm{mM}$, [pyruvate] $=5 \mathrm{mM},[C s A]=0.5 \mu \mathrm{M}$,

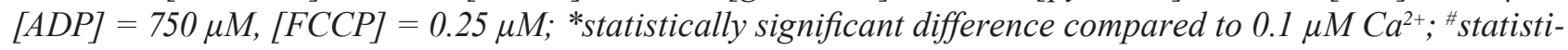
cally significant difference compared to control (without CsA); $n=7$

potential are due to the activation of $\mathrm{MPTP}$ as is argued by the authors.

The results of this study clearly show that $\mathrm{Ca}^{2+}$ accumulation in the mitochondria of permeabilized hepatocytes inhibit both respiratory chain and ATPsythase activity. Respiratory chain activity decrease was caused by activation of mPTP and rescued by CsA. However, the inhibition of ADP-stimulated respiration and oxidative phosphorylation was prevented by CsA only in case of succinate oxidation. This important difference could be explained by the following considerations.

Respiration was inhibited by $\mathrm{Ca}^{2+}$ more strongly and faster in case of NAD-dependent substrates oxidation. This is in agreement with the facts, that $\mathrm{Ca}^{2+}$-capacity of liver mitochondria is higher at succinate oxidation [22] and CsA sensitive $\mathrm{Ca}^{2+}$-induced membrane depolarization of isolated rat liver mitochondria was faster at NAD-dependent substrates oxidation comparing to succinate [21].
The reason for lower sensitivity to $\mathrm{Ca}^{2+}$ of mitochondria at succinate oxidation could be that respiration rates at succinate are higher (2.5-fold in our study), and eventhough succinate oxidation is less efficient in terms of reducing equivalent transport, such difference should account for $\sim 1$.6-fold faster net reducing equivalent transport in respiratory chain. Thus the increased flux of reducing equivalents delays $\mathrm{Ca}^{2+}$-induced depolarisation and pore activation.

Realistically, CsA could only partially inhibit mPTP opening. Thus the diminished pore activity and/or accumulation of $\mathrm{Ca}^{2+}$ per se was enough to inhibit ATP-synthase, but not electron transport chain in case of low mitochondria energization (pyruvate + glutamate + malate).

Thus we conclude that oxidative phosphorylation inhibition is the primary event of mPTP activation, possibly due to ATP-synthase conformation change at pore opening. This is followed by inhi- 
bition of electrone transport chain, most likely via cytochrome $c$ release. While the latter could be associated with apoptosis, the physiological role of oxidative phosphorylation inhibition at MPTP activation is yet to be elucidated.

Conflict of interest. Authors have completed the Unified Conflicts of Interest form at http://ukrbiochemjournal.org/wp-content/uploads/2018/12/ coi_disclosure.pdf and declare no conflict of interest.

Acknowledgement. The research was supported by the grant from the Ministry of education and science of Ukraine (0118U003604, 2018-2020) "Mitochondrial adaptation potential of secretory cells of pancreas and liver in normal and with the development of pathology”.

ВІДКРИТТЯ тРТР ПО-
РІЗНОМУ ВПЛИВАЕ НА
ЕЛЕКТРОНТРАНСПОРТНИЙ
ЛАНЦЮГ ТА ОКИСНЕ
ФОСФОРИЛУВАННЯ ЗА
ОКИСЛЕННЯ СУКЦИНАТУ І
NАD-ЗАЛЕЖНИХ СУБСТРАТІВ
У ПЕРМЕАБІЛЗОВАНИХ
ГЕПАТОЦИТАХ ЩУРІВ

\section{Г. М. Мазур, В. М. Мерлавський, Б. О. Манько, В. В. Манько}

Львівський національний університет
імені Івана Франка, Україна;
e-mail: volodymyr.manko@1nu.edu.ua

Перевантаження мітохондрій $\mathrm{Ca}^{2+}$ може бути тригером відкривання мітохондріальної пори транзієнтної проникності (mРТР), тривала активація якої призводить до загибелі клітин. АТР-синтазу розглядають як можливий молекулярний компонент пори. Мета роботи - дослідження стану окисного фосфорилування за спричиненої $\mathrm{Ca}^{2+}$ активації mPTP у пермеабілізованих гепатоцитах. Гепатоцити ізолювали двостадійним методом Сеглена. Пермеабілізацію гепатоцитів здійснювали дигітоніном. Швидкість споживання кисню визначали за допомогою електрода Кларка. Окисне фосфорилування визначали за співвідношенням ADPстимульованого дихання до субстратстимульованого дихання. Встановлено, що збільшення концентрації $\mathrm{Ca}^{2+}$ у середовищі зумовлює при- гнічення ефектів олігоміцину та знижує швидкість ADP- та FCCP-стимульованого дихання за окислення як сукцинату, так і суміші глутамату, пірувату та малату. Інгібітор mРТР циклоспорин А безпосередньо не впливає на дихання та окисне фосфорилування після підвищення концентрації $\mathrm{Ca}^{2+} \mathrm{i}$ активації mРТР. Якщо циклоспорин А додавали перед підвищенням концентрації $\mathrm{Ca}^{2+}$, робота дихального ланцюга (FCCP-симульоване дихання) не порушувалась, а порушення окисного фосфорилування (ADPстимульоване дихання) було частковим лише за окислення сукцинату. У підсумку, пригнічення окисного фосфорилування $є$ першим наслідком активації mРТP за рахунок, мабуть, залучення АТР-синтази в цей процес. Ефект є сильнішим i швидшим за окислення NAD-залежних субстратів, ніж за окислення сукцинату, що спричинено нижчою енергізацією мітохондрій.

К л ю ч о в і с л о в а: мітохондріальна пора транзієнтної проникності, циклоспорин А, субстрати окислення, гепатоцити, FССР.

\section{References}

1. Gunter TE, Yule DI, Gunter KK, Eliseev RA, Salteret JD. Calcium and mitochondria. FEBS Lett. 2004; 567(1): 96-102.

2. Territo PR, French SA, Dunleavy MC, Evans FJ, Balaban RS. Calcium activation of heart mitochondrial oxidative phosphorylation: rapid kinetics of $\mathrm{mVO}_{2}, \mathrm{NADH}, \mathrm{AND}$ light scattering. J Biol Chem. 2001; 276(4): 2586-2599.

3. Merlavsky V, Ikkert O, Manko V. $\mathrm{Ca}^{2+}$ influence on respiration processes upon streptozotocininduced diabetes mellitus. Visnyk Lviv Univ. Biol Series. 2015; (70): 294-304. (In Ukrainian).

4. Kwong JQ, Molkentin JD. Physiological and pathological roles of the mitochondrial permeability transition pore in the heart. Cell Metab. 2015; 21(2): 206-214.

5. Petronilli V, Penzo D, Scorrano L, Bernardi P, Di Lisa F. The mitochondrial permeability transition, release of cytochrome $\mathrm{c}$ and cell death. Correlation with the duration of pore openings in situ. J Biol Chem. 2001; 276(15): 12030-12034.

6. Bernardi P, Krauskopf A, Basso E, Petronilli V, Blachly-Dyson E, Di Lisa F, Forte MA. The mitochondrial permeability transition from in vitro artifact to disease target. FEBS J. 2006; 273(10): 2077-2099. 
7. Halestrap AP. What is the mitochondrial permeability transition pore? J Mol Cell Cardiol. 2009; 46(6): 821-831.

8. Rasola A, Bernardi P. Mitochondrial permeability transition in $\mathrm{Ca}^{2+}$-dependent apoptosis and necrosis. Cell Calcium. 2011; 50(3): 222-233.

9. Giorgio V, von Stockum S, Antoniel M, Fabbro A, Fogolari F, Forte M, Glick GD, Petronilli V, Zoratti M, Szabó I, Lippe G, Bernardi P. Dimers of mitochondrial ATP synthase form the permeability transition pore. Proc Natl Acad Sci USA. 2013; 110(15): 5887-5892.

10. Chávez E, Rodríguez JS, García G, García N, Correa F. Oligomycin strengthens the effect of cyclosporin A on mitochondrial permeability transition by inducing phosphate uptake. Cell Biol Int. 2005; 29(7): 551-558.

11. Seglen PO. Preparation of isolated rat liver cells. Methods Cell Biol. 1976; 13: 29-83.

12. Crompton $M$, Ellinger $H$, Costi $A$. Inhibition by cyclosporin $\mathrm{A}$ of a $\mathrm{Ca}^{2+}$-dependent pore in heart mitochondria activated by inorganic phosphate and oxidative stress. Biochem J. 1988; 255(1): 357-360.

13. Ponomarenko OV, Babich LG, Gorchev VF, Kosterin SO. Studies of $\mathrm{Ca}^{2+}$-dependent smooth muscle mitochondria swelling using flow cytometry and spermine effects on this process. Ukr Biokhim Zhurn. 2006; 78(6): 38-45. (In Ukrainian).

14. Vergun O, Reynolds IJ. Distinct characteristics of $\mathrm{Ca}^{2+}$-induced depolarization of isolated brain and liver mitochondria. Biochim Biophys Acta. 2005; 1709(2): 127-137.
15. Sparagna GC, Gunter KK, Sheu SS, Gunter TE. Mitochondrial calcium uptake from physiological-type pulses of calcium. A description of the rapid uptake mode. $J$ Biol Chem. 1995; 270(46): 27510-27515.

16. Kröner $\mathrm{H}$. The real kinetics of the mitochondrial calcium uniporter of the liver and its role in cell calcium regulation. Biol Chem Hoppe Seyler. 1988; 369(3): 149-155.

17. Kupynyak NI, Ikkert OV, Shlykov SG, Babich LG, Manko VV. Mitochondrial ryanodine-sensitive $\mathrm{Ca}^{2+}$ channels of rat liver. Cell Biochem Funct. 2017; 35(1): 42-49.

18. McCormack JG. Characterization of the effects of $\mathrm{Ca}^{2+}$ on the intramitochondrial $\mathrm{Ca}^{2+}$-sensitive enzymes from rat-liver and within intact rat-liver mitochondria. Biochem J. 1985; 231(3): 581-595.

19. Johnston JD, Brand MD. Stimulation of the respiration rate of rat liver mitochondria by submicromolarconcentrations of extramitochondrial $\mathrm{Ca}^{2+}$. Biochem J. 1987; 245(1): 217-222.

20. Nicholls DG, Budd SL. Mitochondrial and neuronal survival. Physiol Rev. 2000; 80(1): 315360.

21. Briston T, Roberts M, Lewis S, Powney B, Staddon JM, Szabadkai G, Duchen MR. Mitochondrial permeability transition pore: sensitivity to opening and mechanistic dependence on substrate availability. Sci Rep. 2017; 7(1): 10492.

22. Kondrashova MN, Gogvadze VG, Medvedev BI, Babsky AM. Succinic acid oxidation as only energy support of intensive $\mathrm{Ca}^{2+}$ uptake by mitochondria. Biochem Biophys Res Commun. 1982; 109(2): 376-381. 